\title{
$\mathrm{CAD} / \mathrm{CAM}$ ・コンピュー夕援用技術と教育の現状と今後
}

\section{大村 勝}

$\mathrm{CAD} / \mathrm{CAM} \cdot \mathrm{CAI}$ な゙，コンピュータ援用技術とその 教育について, すべての資料を参照して述べることは不 可能なので，ここでは私の知る限りのせまい範囲の私見 を述べさせていただくことを最初に断っておく。

1989年に CAD／CAM・CIMについて系統的な教育を と考え, 摂南大学に CAD/CAM システムを導入した。当 時, CADと CAMの一貫したシステムを教育用にと考え ても適切なものがあまりなく, データゼネラルのMV-4000 というミニコンに, 三次元金型CADを装備しファナック のワイヤーカットとマシニングセンタを光ファイバーで つなぐことによって DNCを実現させて当時約 9,700 万円 を投資した。端末が14台しかないため，設計製図IIの時間 に 1 班毎週14名づつCADで図面作成を行い, その間, 他 の学生は手書きで課題を仕上げるという, 手書きとCAD の並行授業を行った。この場合, 学生側から見ると 1 年 間に 2 回ぐらい(前期 1 回, 後期 1 回)しか CADに接する ことができず, 三次元の簡単な図面しか作成できなかっ た。CAMの方も当初, DNCでと考えたが製図と実習の 時間がうまくかみ合わず，またCAD側の処理速度が速く, 一度リモートバッファユニットにデータをためてから 1 ジョブごとに機械側に出力させるため, 本来の直接数值 制御するという DNCになっていなかった。当時このシス テムの導入にあたっては, 土木・建築・電気の各学科は 積極的賛成も反対もないままにどちらかといえば批判的 で，いわば「高価なおもちゃで何を教えるのか」という状況 であった。機械工学科と経営工学科の僅かな教員有志の 献身的な努力で導入したのであるが, 上記の次第でカリ キュラム上の問題・時間割の配置の問題など, 多くの困 難に直面して当初試みた CIM システムについては僅かに 卒業研究や研究のみにとどまり完成しなかった。

1993年にCADシステムのみを, ヒューレットパッカー ドのME-10, ME-30のソフトで, 28台の EWS を導入し, 現在CADのみを, そしてCAM は前記のシステムを工場 実習で個別にCAD と関連なく行っている。関西地域の各 大学での CAD／CAM 教育を概観すると一般的に私学の
方が積極的で, 国公立でも CADに熱心な熱血先生のおら れるところではかなりのレベルの教育がなされている。 1996年 3 月21日 日本機械学会関西支部で大学における $\mathrm{CAD} / \mathrm{CAM}$ 教育の現状と問題点というテーマでフォーラ ムを行ったが, CAD と CAM を一貫教育している大学は 見られず，CADはCADのみで，CAMの方はNCテープ 作成後, 数值制御の旋盤やマシニグセンタでの実習のみ である。同学会内に設計製図教育懇談会が1993年より設置 されこのような現状をふまえ, 設計製図教育について精 力的に検討がなされている。教育システム情報学会では, 中学校や高校でのマルチメディアによる教育について図 形以外にインターネットによる国際交流教育などの報告 があり, 図学会においても, 今後これらの課題に対して も，精力的な取り組みが必要と考えられる。

コンピュータ支援技術教育は大学における全教科科目 と連動しており, $\mathrm{CAD}$ み, $\mathrm{CAM}$ の, $\mathrm{CG}$ の, $\mathrm{CAE}$ のみでなくこれらを体系的に履修させる方策を検討すべ きではないだろうか。これらは，機械工学のみではなく， 電気・土木・建築などあらゆる学科を含めて検討される べきであり, $\mathrm{CAD} ・ \mathrm{CAM} ・ \mathrm{CAE} ・ \mathrm{CG} ・ \mathrm{CAI}$ な゙，さら に遠隔教育を含めて教育体系まで考慮しなければならな い。このような視点から考えると, 日本図学会において もこの分野の多面的な展開を必要とし, 今後ますます多 くの課題に対処していかなければならないと思う。

私の理想としては, 仮想生産工場や仮想社会を想定し たマルチメディア教育が, 日本国内はもとより海外との 大学間ともインターネットによってつながり, より効果 的なより現実的な創造教育がなされることである。これ らの実現に向けてはいくつもの困難を解決していく必要 がある。30周年を一区切りにして会員一同一致して, これ らに対処されることを念願したく思う。

おおむら まさる 摂南大学工学部 